\title{
Differential effect of manganese on the germination of Triglochin striata (Juncaginaceae) and Cotula coronopifolia (Asteraceae) in Laguna de Carrizal Bajo wetland, Atacama Region, Chile
}

\author{
Efecto diferencial de manganeso sobre la germinación de Triglochin striata \\ (Juncaginaceae) y Cotula coronopifolia (Asteraceae) en el humedal Laguna de Carrizal \\ Bajo, Región de Atacama, Chile
}

\author{
Nicole Guerrero-Leiva ${ }^{1} 2^{*}$, Claudia Ortiz-Calderón ${ }^{3}$ \& Sergio A. Castro ${ }^{1,2}$ \\ ${ }^{1}$ Laboratorio de Ecología y Biodiversidad, Departamento de Biología, Universidad de Santiago de Chile. Casilla 40, Correo 33, \\ Santiago. Avenida Libertador Bernardo O'Higgins 3363, Santiago, Chile. \\ ${ }^{2}$ Centro para el Desarrollo de la Nanociencia y la Nanotecnología, CEDENNA, 917-0124. Avenida Libertador Bernardo \\ O'Higgins 3363, Santiago, Chile. \\ ${ }^{3}$ Laboratorio de Bioquímica Vegetal y Fitorremediación, Departamento de Biología, Universidad de Santiago de Chile. Casilla \\ 40, Correo 33, Santiago. Avenida Libertador Bernardo O’Higgins 3363, Santiago, Chile. \\ *guerreroleiva.nicole@gmail.com
}

\begin{abstract}
RESUMEN
Manganeso es un metal traza cuyos efectos a nivel de semilla no han sido estudiados en profundidad. En el humedal de Carrizal Bajo se han documentado altos niveles de Mn, como aporte combinado de las actividades antrópicas y de la roca madre. En este estudio se evalua experimentalmente el efecto de distintos tratamientos de Mn $(0,0 ; 0,001 ; 0,1$ y 10,0 ppm) sobre la germinación de Triglochin striata y Cotula coronopifolia, dos macrófitas presentes en el humedal. Nuestros resultados mostraron que la germinación de Cotula disminuyó de 60 a 10 \% en los tratamientos con Mn, mientras que la germinación de Triglochin se mantuvo en torno al $16 \%$, sin mostrar diferencias significativas entre los tratamientos. Estos antecedentes sugieren que Mn puede afectar diferencialmente la germinación de las especies del humedal.
\end{abstract}

\begin{abstract}
Manganese $(\mathrm{Mn})$ is an essential micronutrient for the metabolism of vascular plants (Broadley et al. 2012), but it can be toxic when $\mathrm{pH}$, anaerobic conditions and/or drainage favor its bioavailability and absorption (Millaleo et al. 2010). Various studies have documented that Mn damages adult plants, inducing the appearance of leaf spots (Führs et al. 2008, Kosiada 2013), loss of biomass (Mora et al. 2009, Najeeb et al. 2009), chlorosis (Moroni et al. 2003, Rosas et al. 2007) and necrotic lesions (Moroni et al. 2003). In early stages (i.e., seedlings), the presence of Mn decreases growth (Arya \& Roy 2011, Lee et al. 2011) and causes alterations in stomata formation and root development (Lidon 2002), hindering the absorption of other essential nutrients (Paschke et al. 2005) and results in the death of seedlings (McQuattie \& Schier 2000). The effect of Mn on seeds has been less studied: Santandrea et al. (1997) and Rajjak et al. (2013) showed that at concentrations above 10 ppm the germination of Nicotiana tabacum L. and Triticum aestivum L. is reduced progressively, as a result of oxidative stress and damage of the lipid component of the plasma membrane (Bewley 1986, Todorović 2008). However,
\end{abstract}

there are macrophytes that can tolerate and accumulate high concentrations of trace metals, including Mn (Cooper 1984, Karlsons et al. 2011), thus these have been used for remediation purposes (Najeeb et al. 2009). In this context, to know the ability of seeds to germinate on environments with variable concentrations of $\mathrm{Mn}$, could be important as a first step to ensure the establishment and persistence of remedial species in natural and artificial water systems (Kranner \& Colville 2011).

In the arid ecosystems of the Northern Chile, Mn can be an important trace metal in surface watercourses, with concentrations that can reach 8.0 ppm (DGA 2004). This situation is a consequence of combined contribution of $\mathrm{Mn}$ from the natural erosion of the bedrock and from liquid industrial residues derived from the region's mining activity (DGA 2004). Because Mn can accumulate in coastal marshes and wetlands (Bordean et al. 2014), it is particularly important to evaluate a possible effect on the plants. Thus, the objective of this study was to analyze under laboratory conditions the germinative response of two macrophytes, Triglochin striata Ruiz \& Pav., Juncaginaceae (Triglochin 
hereafter) and Cotula coronopifolia L., Asteraceae (Cotula hereafter), which grow in the Laguna de Carrizal Bajo wetland.

The Laguna de Carrizal Bajo wetland $\left(28^{\circ} 4^{\prime} 60^{\prime \prime} \mathrm{S} ; 71^{\circ}\right.$ 8 ' 35" O) is located on the coast of the Atacama Region (Fig. 1). Its climate is coastal desert, with temperatures of 10 ${ }^{\circ} \mathrm{C}-20{ }^{\circ} \mathrm{C}$ and precipitations that vary between $10-25 \mathrm{~mm}$ per year (Juliá et al. 2008). The flora is composed mainly of species like Distichlis spicata (L.) Greene (Poaceae), Sarcocornia fruticosa (L.) A.J. Scott (Amaranthaceae) and Typha angustifolia L. (Typhaceae). Although they are common species, these taxa were not included in the present study because they do not have seeds available during the sampling season.

In January 2011, ripe fruits of Triglochin and Cotula were collected on the western edge of the wetland. These seeds were collected from 10 individual plants in both species. In the laboratory, were extracted manually near 1,500 seeds of Triglochin and 3,000 of Cotula; seeds collected were assigned to experimental treatments with Mn (GuerreroLeiva 2012). For this proposal, seeds of each species were mixed in order to randomize the effects due to its maternal origin. These seeds were disposed in Petri dishes, covered with culture medium (agar 2\% and Captan fungicide 1\%) enriched with Mn (Guerrero-Leiva 2012). Culture media were prepared with three Mn concentrations: 0.001, 0.1 and $10.0 \mathrm{ppm}$, from a stock solution of $1,000 \mathrm{ppm}$ of $\mathrm{MnCl}_{2}$ in

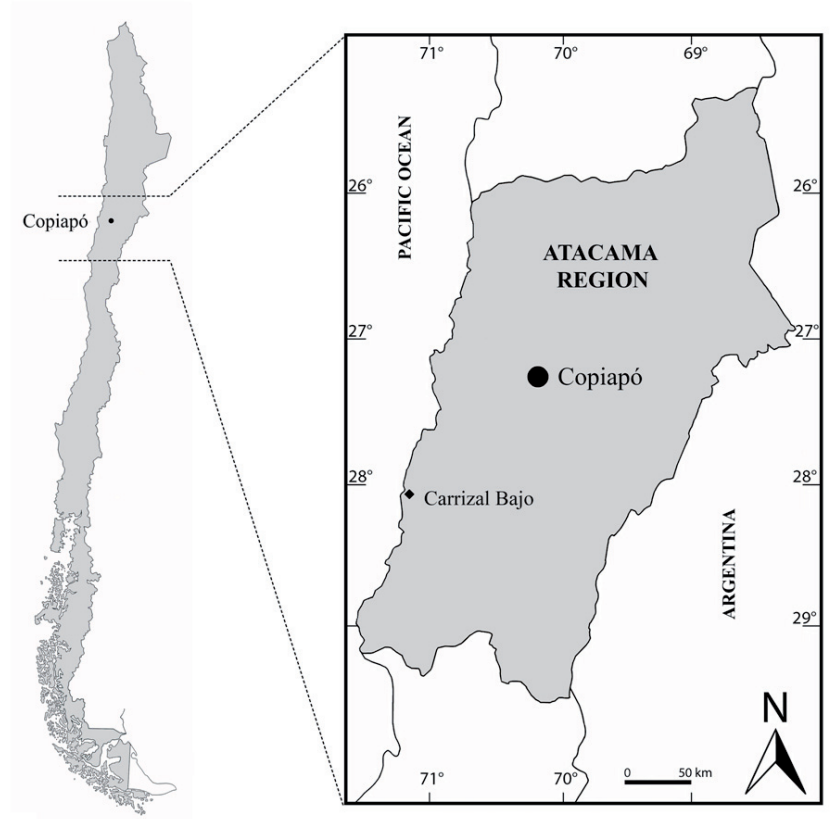

Figure 1. Geographical location of the Laguna de Carrizal Bajo wetland.

FIGURA 1. Localización geográfica del humedal Laguna de Carrizal Bajo.
$\mathrm{H}_{2} \mathrm{O}$ (Merck Titrisol $\left.{ }^{\circledR}\right)$. These were determined based on $\mathrm{Mn}$ concentrations documented in several watercourses in the Northern Chile (DGA 2004). A control treatment (without addition of $\mathrm{Mn}$; $0.0 \mathrm{ppm}$ ) was also established. Although exist evidence that usually the macrophytes require light to germinate (Naidoo \& Naicker 1992, Najeeb et al. 2009), in our preliminary tests in culture media agar (unpublished data) we observed a higher germination of Triglochin and Cotula in darkness. In concordance to this, all the dishes were kept in the dark at temperatures between $22{ }^{\circ} \mathrm{C}$ (day) and $15^{\circ} \mathrm{C}$ (night), in a culture room. According to the
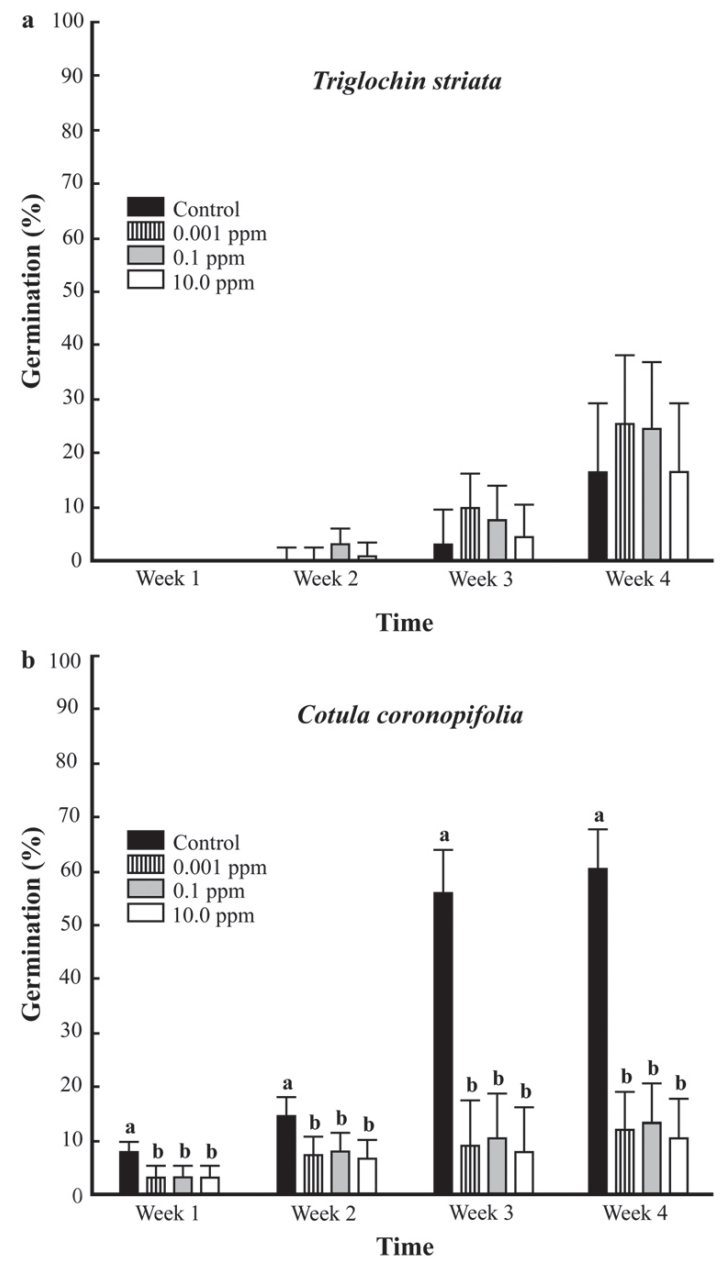

Figure 2. Percentage germination (mean \pm S.D.) accumulated under different $\mathrm{Mn}$ concentrations and control treatment. a) $T$. striata $(\mathrm{P}=0.36), \mathrm{b})$ C. coronopifolia $(\mathrm{P}<0.05)$. The different letters over the bars indicate treatment groups that differ from one another (Tukey test).

FIgURA 2. Porcentaje de germinación (promedio \pm D.E.) acumulado bajo diferentes concentraciones de Mn y tratamiento de control. a) T. striata $(\mathrm{P}=0,36), \mathrm{b})$ C. coronopifolia $(\mathrm{P}<0,05)$. Las diferentes letras sobre las barras indican los grupos de tratamiento que se diferencian entre sí (prueba de Tukey). 
parameters reported by the DGA (2004), $\mathrm{pH}$ is around 7 on watercourses from Northern Chile, so we decided to use this condition in our experiments.

On separate dishes, 30 seeds of Triglochin and 50 of Cotula were sown. In both cases three replicates per treatment were ran. Germination in the dishes was evaluated during one month, recording the germination when the radicle was $\geq 2 \mathrm{~mm}$ long. Then the percentage germination accumulated each week was calculated as $100 \times$ number of germinated seeds $\times$ (number of seeds sown $)^{-1}$. Finally, the accumulated percentage germination was analyzed with repeated measures ANOVA. The Mn concentration (with four levels: $0.0,0.001,0.1$ and $10.0 \mathrm{ppm}$ ) was considered the independent factor, and the percentage germination accumulated (root-transformed) in each week was the dependent variable. When it was relevant, the Tukey test was used as a post hoc test.

The results showed that the presence of $\mathrm{Mn}$ in the culture medium generated differential responses in the germination of Triglochin and Cotula. On the one hand, the germination of Triglochin was not affected (Table I) because the average final germination in the control was $16.7 \%$ ( \pm 5.8 S.D. $)$, while it reached $16.6 \%$ ( \pm 5.8 S.D. $)$ in the highest concentration treatment (10.0 ppm) (Fig. 2a). On the other hand, the germination of Cotula was reduced significantly (Table I); in the control the average final germination was $60.7 \%$ ( \pm 8.5 S.D.) while in the highest concentration treatment $(10.0 \mathrm{ppm})$ the average final was $10.7 \%$ ( \pm 5.5 S.D.) (Fig. 2b). Interestingly, the effect on Cotula was not dose-dependent because in all the Mn treatments the germination was reduced with respect to control (Fig. 2b).

In this study we performed a first approach to observe the effect of Mn upon germination of Triglochin and Cotula, under laboratory conditions that are not necessarily generalizable to the field conditions. Thus, the results should be carefully interpreted in terms of its scope and limitations. First, the $\mathrm{pH}$ conditions determine the oxidation state and therefore the metal bioavailability. In our trials, we only use neutral $\mathrm{pH}$ as condition following value documented by DGA (2004) for superficial water from Northern Chile. Second, because the seeds were collected in a site with high concentration of $\mathrm{Mn}$, an important aspect to study is analyze the possible maternal uptake of this trace elements during seed formation (Kranner \& Colville 2011), and how this contribution could have conditioned the germination response of species. However, our findings are a valuable first step to begin to understand how the presence and concentration of $\mathrm{Mn}$ affects a critical stage of the life cycle (i.e. the seed) of the macrophytes studied.

A question that arises from the results is: why did the germination of Triglochin not respond to the experimental levels of Mn? According to current studies can be suggested that genus Triglochin have a greater capacity to tolerate environments enriched with $\mathrm{Mn}$. In fact, studies made on other species as Triglochin maritima L. (Cooper 1984) have shown that this taxa has the ability to germinate and grow in media enriched with $\mathrm{Mn}(>275 \mathrm{ppm})$ without morpho-physiological damage. Additionally, Cooper (1984) and Karlsons et al. (2011) have reported that Triglochin maritima and Triglochin palustre L. can accumulate trace metals as $\mathrm{Mn}, \mathrm{Cu}, \mathrm{Fe}$ and $\mathrm{Zn}$, while Triglochin striata can accumulate $\mathrm{Mn}, \mathrm{Cu}, \mathrm{Fe}, \mathrm{Zn}, \mathrm{Cd}, \mathrm{Cr}$ and $\mathrm{Pb}$ (Chenhall et al. 1992, Almeida et al. 2011). Longer duration experiments may test the ability of seedling establishment of Triglochin striata under field conditions.

TABLE I. Repeated measures ANOVA for the germination of Triglochin and Cotula in response to the concentration of Mn in the culture medium over time.

TABLA I. ANOVA de medidas repetidas para la germinación de Triglochin y Cotula en respuesta a la concentración de Mn en el medio de cultivo, a lo largo del tiempo.

\begin{tabular}{lccccc}
\hline \multicolumn{1}{c}{ TRIGLOCHIN } & SS & DF & MS & F & P \\
\hline Concentration & 6.9 & 3 & 2.3 & 1.2 & 0.367 \\
Time & 93.4 & 2 & 46.7 & 96.6 & $<0.001$ \\
Concentration $\times$ Time & 3.8 & 6 & 0.6 & 1.3 & 0.306 \\
\hline \multicolumn{1}{c}{ COTULA } & SS & DF & MS & F & P \\
\hline Concentration & 67.9 & 3 & 22.6 & 44.6 & $<0.001$ \\
Time & 45.6 & 3 & 15.2 & 94.1 & $<0.001$ \\
Concentration $\times$ Time & 24.8 & 9 & 2.76 & 17.0 & $<0.001$ \\
\hline
\end{tabular}


Although $\mathrm{Mn}$ is an essential micronutrient (Broadley et al. 2012), its presence in all treatments drastically reduced the germination of Cotula. The experiments do not allow determining the causal mechanism of this effect, but future trials could establish whether the presence of Mn slows the germination or causes the death of seeds (Bewley 1986, Todorović et al. 2008, Kranner \& Colville 2011). Possible responses may be related to bioavailability of manganese under $\mathrm{pH}$ levels, the permeability of the seed coat and possible dormant state of ungerminated seed.

In localities of northern Chile the concentration of $\mathrm{Mn}$ in watercourses can vary over a range of 0.01 to $8.0 \mathrm{ppm}$ (DGA 2004). These levels exceed the Chilean standard NCh1333 for this metal (0.20 ppm; INN-Chile 1987), so it is very important to determine not only the sources (i.e., natural versus anthropic), but also their effect on the conservation for the local biota (Marquet et al. 2012). Our results indicate that it is relevant to carry out studies to evaluate the ability of the flora associated with these ecosystems to tolerate and accumulate Mn (as well as other trace elements) as potential remediation taxa, and at the same time directing efforts to detect taxa whose local persistence is compromised as a consequence of high concentration of $\mathrm{Mn}$, like those detected in the Laguna de Carrizal Bajo wetland.

\section{ACKNOWLEDGEMENTS}

The authors acknowledge gratefully the support of CORFOINNOVA Project 09CN14-5795, FONDEF ID14I10151 and Center for the Development of Nanoscience and Nanotechnology CEDENNA FB0807 - Line 6

\section{REFERENCES}

Almeida, C.M.R., A.P. Mucha \& M.T. Vasconcelos. 2011. Role of different salt marsh plants on metal retention in an urban estuary (Lima estuary, NW Portugal). Estuarine, Coastal and Shelf Science 91(2): 243-249.

Arya, S.K. \& B.K. Roy. 2011. Manganese induced changes in growth, chlorophyll content and antioxidant activity in seedlings of broad bean (Vicia faba L.). Journal of Environmental Biology 32(6): 707-711.

Bewley, D.J. 1986. Membrane changes in seeds as related to germination and perturbations resulting from deterioration in storage. In: M.B. McDonald \& C.J. Nelson (eds.), Physiology of Seed Deterioration, pp 27-45. Crop Science Society of America, Inc., USA.

Bordean, D.M., D.V. Nica, M. Harmanescu, I. Banatean-Dunea \& I.I. Gergen. 2014. Soil Manganese enrichment from industrial inputs: a gastropod perspective. PLoS ONE 9(1): e85384.

Broadley, M., P. Brown, I. Cakmak, Z. Rengel \& F. Zhao. 2012. Function of Nutrients: Micronutrients. In: P. Marschner (ed.), Marschner`s Mineral Nutrition of Higher Plants, Vol.
1, pp. 191-248. Academic Press, San Diego, USA.

Chenhall, B.E., I. Yassini \& B.G. Jones. 1992. Heavy metal concentrations in lagoonal saltmarsh species, Illawarra region, southeastern Australia. The Science of the Total Environment 125: 203-225.

Cooper, A. 1984. A comparative study of the tolerance of salt marsh plants to manganese. Plant and Soil 81(1): 47-59.

DGA (Dirección General de Aguas). 2004. Diagnóstico y clasificación de cursos y cuerpos de agua según objetivos de calidad. URL: http://www.sinia.cl/1292/w3article-31018.html

Führs, H., M. Hartwig, L. Buitrago, D. Heintz, A. van Dorseelaer, H. Braun \& W. Horst. 2008. Early manganese-toxicity response in Vigna unguiculata L. - a proteomic and transcriptomic study. Proteomic 8: 149-59.

Guerrero-Leiva, N. 2012. Efecto de metales integrantes de RILes mineros sobre la germinación de Triglochin striata R. et P. y Cotula coronopifolia L. presentes en el humedal Laguna Carrizal Bajo, III Región de Atacama, Chile. Tesis. Biólogo. Instituto de Biología, Pontificia Universidad Católica de Valparaíso. Valparaíso, Chile. 43 pp.

INN-Chile (Instituto Nacional de Normalización). 1987. Norma chilena 1333. Of78. "Requisitos de calidad de agua para diferentes usos".

Juliá, C., S. Montecinos \& A. Maldonado. 2008. Características climáticas de la Región de Atacama. En: F.A. Squeo, G. Arancio \& J.R. Gutiérrez (eds.), Libro Rojo de la Flora Nativa y de los Sitios Prioritarios para su Conservación: Región de Atacama, pp. 25-42. Ediciones Universidad de La Serena, La Serena, Chile.

Karlsons, A., A. Osvalde \& G. Ievinsh. 2011. Growth and mineral nutrition of two Triglochin species from saline wetlands: adaptation strategies to conditions of heterogeneous mineral supply. Environmental and Experimental Biology 9: 83-90.

Kosiada, T. 2013. The effects of manganese and other factors on the formation of spots on leaves of barley (Hordeum vulgare L.). Fresenius Environmental Bulletin 22: 11321138.

Kranner, I. \& L. Colville. 2011. Metals and seeds: Biochemical and molecular implications and their significance for seed germination. Environmental and Experimental Botany 72: 93-105.

LeE, T.J., B.P. Luitel \& W.H. Kang. 2011. Growth and physiological response to manganese toxicity in Chinese cabbage (Brassica rapa L. ssp. campestris). Horticulture Environment and Biotechnology 52(3): 252-258.

LIDON, F. 2002. Rice plant structural changes by addition of excess manganese. Journal of Plant Nutrition 25(2): 287-296.

Marquet, P.A., S. Abades \& I. Barría. 2012. Distribución y conservación de humedales costeros: una perspectiva geográfica. In: M.J. Fariña \& A. Camaño (eds.), Humedales costeros de Chile, pp. 1-19. Ediciones Universidad Católica de Chile, Santiago, Chile.

McQuattie, C.J. \& G.A. Schier. 2000. Response of sugar maple (Acer saccharum) seedlings to manganese. Canadian Journal of Forest Research 30(3): 456-467.

Millaleo, R., M. Reyes-Díaz, A.G. Ivanov, M.L. Mora \& M. Alberdi. 2010. Manganese as essential and toxic element for plants: transport, accumulation and resistance 
Mn effect on the germination, Triglochin and Cotula: Guerrero-LeIva, N. ET AL.

mechanisms. Journal of Soil Science and Plant Nutrition 10(4): 470-481.

Mora, M., A. Rosas, A. Ribera \& R. Rengel. 2009. Differential tolerance to $\mathrm{Mn}$ toxicity in perennial ryegrass genotypes: involvement of antioxidative enzymes and root exudation of carboxylates. Plant and Soil 320: 79-89.

Moroni, J., B. Scott \& N. Wratten. 2003. Differential tolerance of high manganese among rapseed genotypes. Plant and Soil 253: 507-519.

Naidoo, G. \& K. Naicker. 1992. Seed germination in the coastal halophytes Triglochin bulbosa and Triglochin striata. Aquatic Botany 42: 217-229.

Najeeb, U., L. Xu, S. Ali, G. Jilani, H. Gong, W. Shen \& W. Zhou. 2009. Citric acid enhances the phytoextraction of manganese and plant growth by alleviating the ultrastructural damages in Juncus effusus L. Journal of Hazardous Materials 170: 1156-1163.

Paschke, M.W, A. Valdecantos \& E.F. Redente. 2005. Manganese toxicity thresholds for restoration grass species. Environmental Pollution 135(2): 313-322.

Rajuak, I., P. Rajuak, R. Ahmed \& A. Abdulla. 2013. Phytotoxic effects of heavy metals $(\mathrm{Cr}, \mathrm{Cd}, \mathrm{Mn}$ and $\mathrm{Zn})$ on wheat (Triticum aestivum L.) seed germination and seedling growth in black cotton soil of Nanded, India. Research Journal of Chemical Sciences 3(6): 14-23.

Rosas, A., Z. Rengel \& M. Mora. 2007. Manganese supply and $\mathrm{pH}$ influence growth, carboxylate exudation and peroxidase activity of ryegrass and white clover. Journal of Plant Nutrition 30: 253-270.

Santandrea, G., S. Schiff \& A. Bennici. 1997. Manganese toxicity to different growth processes in vitro in Nicotiana. Plant Cell, Tissue and Organ Culture 50: 125-129.

Todorović, S., Z. Giba, G. Bačić, M. Nikolic \& D. Grubišić. 2008. High seed Mn content does not affect germination of in vitro produced Centaurium pulchellum seeds. Environmental and Experimental Botany 64: 322-324.

Recibido: 16.09 .14

Aceptado: 10.03.16 